\title{
ALMAN GELIR VERGISI
}

\section{Yazan: Doçent Dr. Avni ZARAKoLU}

\section{Tarihce :}

Bazı maliyeciler modern gelir vergilerinin, menkûl irad vergileri ve baş vergisi gibi, iki eski verginin tekâmülünden meydana geldiğini iddia etmektedirler (1). Alman gelir vergisinin menşei baş vergisidir.

Almanya, iddihadını XIX uncu Asrın ikinci yarısında tahakkuk ettirmiş, federasyon şeklinde idare edilen bir memlekettir. 1920 ye kadar, federasyona dahil devletlerin her birinde birbirinden az çok farklı vergi sistemleri cari idi. Bununla beraber, daha XIX uncu Asırda bas vergilerinin iktidara göre alınmaya başlaması, bütün federe devletlerde gelir vergisinin tatbikini kolaylaştırmış ve gelir vergisi Birinci Dünya Harbinden evvel bütün Almanyada yerleşmiştir. Meselâ Prusyada 1820 tarihinde, Fransiz reel vergilerinden mülhem olarak almmakta olan arazi, bina ve kazanc vergilerini itmam etmek maksadiyle, vatandaşlarm servetine göre derecelenmiş bir smıf vergisi konulmuş, bu vergi 1851 tarihinde senelik muhammen gelirleri 1000 Taleri aşan mükellefler için umumi bir gelir vergisi haline getirilmiștir. Bu vergide beyanname mükellefiyeti mevcut değildi. Fakat, asgari geçim indirimi, vergi nisbetinin gelire göre \% 0,6 - 2,7 arasında değişmesi suretiyle, şahsiyet prensibi az çok göz önünde bulunduruluyordu.

Almanyada, bu günki anlamda bir gelir vergisi, ilk defa Hessen'de (1869) Saksonyada (1874), Baden'de (1884) konulmuş olup, Birinci Dünya Harbi'ne kadar bütün Alman devletlerinin vergi sistemlerine girmiştir.

Prusya, hakikî mânada gelir vergisine 1891 de Miquel vergi reformu ile kavuşmuştur. Birinci Dünya Harbi'ne kadar diğer bir çok Alman gelir vergilerine esas olan 1891 tarihli Prusya gelir vergisi kanunu, bu günki kurumlar vergisinin de esasını vazetmiştir. Fakat zamanımızdakinden farklı olarak, kurumlar vergisinin sebebiyet vereceği çifte vergi yükünü hafifletmek maksadiyle, matrahtan şirket sermayesinin $\% \quad 3,5$ $u$ nisbetinde bir indirim yapılması kabul edilmiștir. Diğer taraftan, önceleri vergiden muaf tutulan bir kısım aileler, vergiye dahil edilmek su-

(1) J. Popitz: Einkommensteuer (Geschichte und geltendes Recht), in : Handwörterbuch der Staatswissenschaften. 
retiyle, umumiyet prensibinin tahakkukuna çalışılmıştır 2). 1891 tarihli Prusya Gelir Vergisi Kanunu, gelir mefhumunun tayininde menba teorisinden mülhem olmuştur. Bilindiği gibi bu teori, gelirde intizam ve mevkutluk şartını aramaktadır.

Gelirin dört kaynağı vardır:

1. Menkul servetlerden elde edilen gelirler,

2. Gayri menkul servetlerden elde edilen gelirler,

3. Ticaret ve sanayiden elde edilen gelirler,

4. Bağlı ve serbest meslekten elde edilen gelirler.

1891 tarihli kanunun diğer vasıfları meyanında, masraf indirimi, asgari geçim indirimi, vergi nisbetlerinde müterakkiyet $(\% \quad 0,6-6)$ ilh. sayılabilir. Ayırma prensibi zamanımızda olduğu gibi, 1893 de vazedilen umumi bir servet vergisi ile temin edilmektedir. Maksat müemmen gelirleri daha yüksek vergiye tabi tutmaktır. Fakat zamanımızda ödenen servet vergileri gelir vergisi matrahından indirilmektedir.

Almanyada gelir vergisinin yanında yer alan ve öteden beri tatbik edilmekte olan reel vergiler belediyelere bırakılmış, ayrıca belediyelere, federe devletin gelir vergisine \% 200 e yakın zam yapabilmek hakkı taninmiştıx.

1871 de kurulan Alman Reich'ine gelince, Reich'e istihlâk, muamele ve gümrük vergileri gibi vasıtalı vergiler tahsis edilmiștir. Fakat Reich bununla kalmamıştır. Devlet masraflarının artması, vergi kaynaklarının genişletilmesi zaruretini ortaya çıkarmıştır: 1913 de Reich'e servet artışı üzerinden vergi almak, harp içinde gelir vergisine iştirâk hakkının tanımması gibi (3).

Birinci Dünya Harbi, diğer sahalarda olduğu gibi, gelir vergisinde de büyük değişiklik meydana getirmiştir. Her şeyden evvel Reich'm direkt vergilere müdahalesine karşı mukavemetin zayıfladığına işaret ètmek lâzımdır. Nitekim, 1920 de Reich tarafından bütün Almanya için yeni bir gelir vergisi kanunu hazırlanarak kabul edildi. Federe devletlerin gelir vergilerinin ve belediye zamlarmm yerine geçen bu verginin tarh ve tahakkuk işi de Reich vergi idaresine bırakıldı.

1920 tarihli gelir vergisi, bundan evvelki federe devletlerin gelir vergilerinden mühim farklar arzetmektedir. Bunları şöyle hulasa edebiliriz :

(2) J. Popitz : a.g.e.

F. Neumark: Theorie und Praxis der modernen Einkommenbesteuerung, Bern 1947 S. 220.

(3) Muhtelif vergi hasilatmin, merkezi devlet, federe devletler ve belediyeler arasında bu taksim sistemi aşağı yukarı bu gün de caridir. 
1 - Gelir mefhumu genişletilmiştir. Bilhassa, Prusyada kuvvetle müdafaa edilen menba teorisi terkedilerek, patrimuvandaki her artıs gelir sayılmıştır. Gelirin vergiye tabi tutulması için, devamlı bir menbaa dayanmasina ve mevkut bulunmasina lüzum yoktur. Bir defaya mahsus olarak elde edilen gelirler de vergiye tabidir.

2 - Gelir vergisi sadece hakikî şahıslara münhasır bırakılarak, şirketler hususi bir vergiye, yani kurumlar vergisine tabi tutulmuştur. Bu şekilde istiyerek bir mükerrerlik meydana getirilmektedir.

3 - Vergi mükellefi bakımından aile esastır. Kadının ve aile bütçesine dahil rüşte vasıl olmamış çocukların gelirleri, kocanın gelirine ilâve edilerek vergilenir.

4 - Vergide şahsilik muhtelif şekilde temin edilmiştir, Ezcümle asgari geçim indirimi ailenin durumuna ve çocuk adedine göre değişmektedir.

5 - Verginin tarh ve tahakkukunda beyanname usulü caridir. Bununla beraber, ücretler gibi bazı gelirlerin vergileri menbada kesilmektedir.

6 - Vergi nisbeti, harpten öncekine nazaran çok yükseltilmiş olup, \% 10 - 60 arasında değişmektedir.

Esaslarını belirtmeğe çalıștığımız 1920 tarihli gelir vergisi kanunu, 1920 - 1923 arasinda Almanyada meydana gelen büyük enfilasyon yüzünden gereği gibi tatbik edilememiş, 1923 Alman para reformundan sonra ve Hitler idaresi altında bir takım vergi reformları yapilmıştır. Bununla beraber, Alman gelir vergisinin, 1925 de konulan esasları muhafaza ettiği söylenebilir.

İkinci Dünya Harbi sona erdiği zaman, 1934 tarihli gelir vergisi ve 1939 tarihli kurumlar vergisi bazı tadillerle tatbik edilmekte idi. İsgal kuvvetleri, mevcut gelir ve kurumlar vergisini, vergi tarifesinde yaptıkları değişikliklerle aynen tatbik etmişlerdir. Bu gün carî bulunan 1949 ve 1950 kanunları aynı esasları ihtiva etmektedir. Nitekim, bu günki Alman Gelir Vergisi, 1925 de olduğu gibi, iki esas vergiye dayanmaktadir :

1. Hakiki şahısların gelirlerinden alınan gelir vergisi,

2. Hükmi şahısların gelirlerinden alman kurumlar vergisi.

Yazımızda, önce hakikî şahısların gelir vergisinden bahsedeceğiz, bilahare kurumlar vergisini anlatmağa ve Alman Gelir Vergisinin tümü hakkmda bir hükme varmağa çalışacağız. 
Gerçek kişilerin gelirierinden alınan gelir vergisi yanında, şirketlerin geliri üzerinden ayrı bir vergi alınması bir takım itirazlara yol açmıştır. Bunu yazımızın sonunda tetkik edeceğiz.

\section{GELIR VERGISI}

\section{Gelir vergisinde mükellef :}

Alman gelir vergisinde mükellef, biraz evvel işaret ettiğimiz gibi, hakikî şahıslardır. 10 Ağustos 1949 tarihli Alman Gelir Vergisi Kanununun birinci paragrafına göre, mükellefler, mahdut ve gayrı mahdut şekilde gelir vergisine tabi olmak üzre ikiye ayrılmıştır: 1 - Almanya'da ikametgâhı bulunan veya mutaden Almanyada oturan hakikî şahıslar bütün gelirleri üzerinden gayri mahdut şekilde vergiye tabidirler (tam mükellefiyet). 2 - Buna mukabil, Almanyada ikametgâhı bulunmıyan veya mutad olarak oturmıan hakikî şahıslar, sadece Almanyada elde ettikleri gelirler üzerinden vergiye tabidirler (dar mükellefiyet) (4).

29 Nisan 1950 tarihli gelir vergisini tadil eden kanunla, gelir vergisi kanununun birinci paragırafına bir fıkra ilâve edilerek (fıkra: 3), Almanya dahilinde ikametgâhı olmıyan, fakat Almanyaya ait bir yerde ikamet eden veya oturan kimselerin de ikinci fıkrada olduğu gibi, mahdut bir şekilde gelir vergisine tabi tutulması kabul edilmiştir. Bu suretle Rus Bölgesinde oturan kimselerin Garbi Almanyada elde ettikleri gelirlerin dar mükellefiyete tabi olacağı kabul edilmiştir (5).

Türk Gelir Vergisi Kanununun 2 inci ve müteakip maddelerindeki hükümlere tetabuk eden bu paragraf, vergide umumiyet prensibine uygundur. Bununla beraber, Birleşmiş Milletlere mensup askerler, Birleşmîs Milletler'e ait askerî birliklerde çalışan ve Alman olmıyan şahıslar, Birleşmiş Milletlerin yardımcı teşkilâtı ve bu teşkilâtta çalışan yabancılar Alman Gelir Vegisi'nden muaf tutulmuşlardır (6). Aynı şekilde Dünya Bankası ve Para fonunun Almanyadaki memurlarına ödedikleri paralar gelir vergisine tabi değildir (7).

Bunun yanında zamanimızda vergide umumiyet prensibine riayetin şekli olduğunu, bir kısım aşırı muafiyetler ve bir kısım sınıfların çok

(4) Gelir vergisi nizamnamesine göre, Almanya dahili tabirinden 4 ' isgal bölgesi ve Berlin anlaşılmaktadır. Sar bölgesi için hususi bir nizamname yapılması kararlaștırılmıştır.

(5) Die Einkommensteuer - Richtlinien für den Veranlagungszeitraum 1950.

(6) Einkommensteuer, Richtlinien $I / 1948$ und 1949, Verwaltungsordnung.

(7) K. Wieneke: Die Einkommensteuer - Ergänzungsrichtlinien für die Veranlagugszeit 1952, Neus Steuerrecht, Lieferung 165 vom 15/6/1953. 
ağır vergiye tabi tutulması, Orta çağdaki imtiyazlı sinıfların muafiyetlerini geride birakacak şekilde umumiyet prensibini ihlal ettiğini iddia edenler de vardır (8). Bu konuya yazımızın sonunda avdet edeceğiz.

\section{Gelir methumu :}

Alman Gelir Vergisinin tarihçesinden bahsederken, 1920 tarihli gelir vergisi kanunu ile, tamamen kaynak teorisine dayanan eski dar anlamda gelir mefhumu terkedilerek, patrimuandaki artış teorisine dayanan geniş anlamda gelir mefhumuna kayıldığına işaret etmiştik. Bu esas zamanımizda da caridir. Filhakika, 1949 tarihli gelir vergisi kanununun ikinci paragrafında, gelir vergisinin, mükellefin bir takvim yılı içinde elde ettiği gelir üzerinden alınacağı kaydedilmekte ve gelir neşet ettiği menbalara göre, 7 kalemde gösterilmektedir. Bunlar :

1 - Ziraî kazançlar

2 - Sinaî ve ticarî kazançlar

3 - Serbest meslek erbâbının kazançlamı

4 - Ücretler

5 - Menkul sermaye iradları

6 - Gayri menkul sermaye iradları

7 - Diğer iradlardan (22 inci paragraf anlaminda) terekküp etmektedir.

Vergiye tabi gelirin hesabında, diğer iradlarm ilâvesi, işletme ve tesisatın satılmasından tevellüt eden kazançların gelir mefhumuna ithal edilmesi, gelir mefhumunun geniş anlamda kabul edilmesinin bir neticesidir. Ziraat, ormancılık, sanayi ve ticaretle meşgul olan şahısların ve serbest meslek erbabının ticarî mânada elde ettikleri bütün kazançları ve diğer menbalardan elde edilen gelir fazlaları gelir vergisine tabidir. Vergi hakikî ve safi gelir üzerinden almmaktadır.

Gelirin hesap ve tesbit şekline geçmeden önce, bu muhtelif gelir nevilerini kısaca izah edelim :

\section{1 - Zirầ kazançlar :}

Alman Gelir Vergisi Kanunu'nun 13 üncü paragırafma göre,

a. Ziraat, ormancılık, bağcılık, bağçecilik gibi, nebat yetiştirilmesi ile uğraşan ziraî işletmelerin kazançları,

b. Hayvanciliktan,

c. Balıkeiliktan,

(8) Schmölders: Die Notwendigkeit der organischen Steuerreform, in : Finanzarchiv, Bd: 14; Heft: 1, Tübingen 1953. 
d. Avcıliktan temin edilen kazançlar ve

e. Ziraat ve ormancılığa bağlı tali işletme gelirleri,

f. Mükellefin oturduğu, şahsina ait evin kullanma değeri ziraî kazanç meyanına girmektedir. Bundan başka, ziraî işletmelerin satışından mütevellit kazançlar 10000 markı aştığı taktirde gelir vergisine tabi tutulmaktadır (paragıraf: 14).

Kanun, defter tutma mükellefiyeti olmıyan çiftçiler için asgarî bir had tâyin etmiştir. Senelik geliri 6000 markı aşan çiftçiler, gelirlerinin temamı üzerinden gelir vergisine tabi tutulmuş olup, 6000 markı aşmıyan gelirlerde 1000 markı vergiden muaf tutulmuştur. 1945 senesinden sonra Almanya'ya gelen muhacirler için muafiyet haddi 2000 marktır. Demekki, senelik ziraî kazancı 2000 Markı aşmıyan muhacirlerle 1000 Markı aşmıyan yerli çiftçiler ziraî kazançlarından dolayı gelir vergisine tabi olmiyacaklardır.

Ziraî gelirlere tatbik edilen bu hususî muamele, bu mesleğin mahiyeti ile az çok ilgilidir. Nitekim yarı kapitalist bir karekteri haiz bulunan ziraî işletmeler, İkinci Dünya Harbi'nden önce daha geniş bir muafiyetten faydalanmakta idiler (9). Mamafi, 1930 Dünya Ekonomi Krizinin tesirlerinden Alman Ziraatini korumak düşüncesinin ve Almanyanın takip ettiği otarşi siyasetinin de bunda büyük rolü olmuştur denilebilir (10).

\section{2 - Sinaî ve ticarî kazançlar (Paragraf: 15 - 17) :}

Maden ve taş ocakları da dahil olmak üzere, sanayi ve ticaretten elde edilen kazançları ihtiva eder. Şirketlerin gelirleri, kurumlar vergisi namı altında ayrı bir vergiye tabi olduğuna göre, burda sadece hakikí şahısların sanayiden ve ticaretten elde ettikleri kazançlarm mevzuu bahsolduğunu tekrar etmeğe lüzum yoktur. Bu hale göre, bir anonim şirketin malik bulunduğu bir fabrikadan elde ettiği kazanç hissedarlara taksim edildikten sonra, hissedarlarm diğer gelirleri ile birlikte gelir vergisine tabi tutulacak demektir.

Sınaî ve ticarî kazançlara, tı̣kkı ziraatte olduğu gibi, sınaî ve ticarî teşebbüslerin tamamen veya kısmen satılmasından husule gelen ve

(9) Neumark: Theorie und Praxis der modernen Einkommensteuerung, S. $238-239$.

(10) Alman Gelir Vergisini örnek alan gelir vergisi kanunumuzda, gelirler altı menbaa bölünmütür. Bu fark, memleketimizde zirâ̂ kazançların gelir - vergisinden temamen istisna edilmesinden ileri gelmektedir. Diğer gelir nevileri AIman Gelir Vergisindeki gelir nevilerine büyük çapta intibak etmektedir. 
10000 Markı aşan kısmı da dahildir. Bahse mevzu kâr, satış bedelinin 4 üncü paragrafa göre, değeri tayin edilen teşebbüs sermayesi ve satış için ihtiyar edilen masrafları aşan kısmına müsavidir.

Görülüyorki Alman Gelir Vergisi Kanunu, vergiye tabi geliri tayin ederken, menba teorisinin dar hudutları içinde kalmıarak, geliri patrimuandaki artma şeklinde anlamağa mütemayildir.

3 - Serbest meslek erbabinm kazancı (parafraf: 18):

Serbest meslekten, doktor, avukat, noter, mühendis, hesap uzmanı gibi iktisaden müstekil ve daha ziyade mükellefin şahsi emek ve faaliyetine dayanan meslekler anlaşılmaktadır. Bu gibi kimselerin mesleki faaliyetlerinden elde ettikleri gelirleri ile Devlet Piyangosundan temin edilen piyango kazançları, vasiyetnamelerin icrasını idare eden yedi eminlerin gelirleri, serbest meslek erbabinin kazancı kategorisine girmektedir. Serbest meslek faaliyetinin daimî veya muvakkat olmasmin vergi bakımından bir ehemmiyeti yoktur. Bundan başka, ticarî ve ziraî kazançlarda olduğu gibi, mesleğe ait sermaye mallarının satışından temin edilen kazançlar nazarı itibare alınmaktadır.

\section{4 - Ücretler (paragraf: 19):}

Ücret tabirini geniş mânada anlamak lâzımdır. Bağlı bir say neticesi temin edilen hertürlü maaş, yevmiye, ikramiye, nakti mükâfat ve kâra iştirâkler bu gelir kategorisine girdiği gibi, tekaüdiyeler de gelir vergisi bakımından ücret sayılmaktadır. Onun için bu gelir kategorisine, Neumark'ın aksine olarak, ücret yerine Almanca tabirinin tam mukabili olan bağlı emek geliri demek daha yerinde olabilir.

Is verenin, işçi tarafından kendi yerine ödediği masraflara tekabül eden tediyeleri ve işçinin yol masrafları ücrete dahil edilmez.

\section{5 - Menkul sermaye iradlarn (paragraf: 20):}

Diğer irad nevilerine girmiyen, kâr hisseleri (dividant), faizler gibi nakti sermaye semerelerinden terekküp etmektedir.

\section{6 - Gayri menkul sermaye iradlari (paragraf: 21):}

Bu tabir gelir vergisi kanunu tarafından oldukça geniş bir mânada kullanılmıştır: Gayrimenkûl ve vapur kiraları, mükellefin bizzat oturduğu evinin kirası, mütehavvil ișletme sermayesinin kiralanmasindan mütevellit gelirler, telif hakkı, ihtira beratı gibi hakların muayyen müddet başkasına terkinden mütevellit iradlar, icar alacaklarının devrinden elde edilen kârlar bu gelir kategorisine girmektedir. Eğer bu nevi gelir. 
ler, menkul sermaye iradlarında olduğu gibi, başka gelir kategorilerine dahil edilmişse, bu kategoriden düşülür.

\section{7 - Diğer iradlar (paragraf: $22-23$ ):}

Yukarda saydığımız altı kategoriye dahil olmıyan iradlar bulunabilir. Bu iradlar devri veya tamamen tesadüfe bağlı olarak meydana gelebilirler. Ezcümle, tevarüs edilen rantlar, spekülasyon kazançları, senede asgarî 300 Markı geçmemek şartiyle menkul mal icarından mütevellit iradlar gibi.

Kanun, oldukça kaypak bir mefhum olan spekülasyon üzerinde durmuş ve bunun için ayrı bir paragraf vazetmiştir. Alman vergi kanununa göre, bir muamelenin spekülasyon muamelesi telâkki edilebilmesi için, alınan mal ve kıymetli senetlerin, gayrı menkullerde iki seneden az bir zaman içinde, menkul mallarda ve bilhassa krymetli kâğıtlarda ise, bir-seneden evvel tekrar satılması icabeder. Bilhassa alıs muamelesinden evvel yapilan satışlar spekülasyona delalet eder.

Bununla beraber, kanun bazı muameleleri spekülasyon dışı saymıstır. Ezcümle, ikametgâhı veya iş merkezi Almanyada bulunan borçluların rant kâğıtları almaları, resmi borç defterine kayıtlı alacaklar, Alman Devlet Demiryollarını imtiyazlı hisse senetlerinin almıp satılması spekülasyon sayılmamaktadır. Bundan başka spekülasyon gelirinden bahsedebilmek için, elde edilen gelirin diğer gelir guruplarına girmemiş olması lâzımdır. Spekülasyon geliri alış fiyatı ile satış fiyatı arasındaki farka müsavidir. Bu farkın vergiye tabi olabilmesi için 1000 Markı aşmasi lâzımdır.

\section{Gelirin tesbiti :}

Gelir vergisi, yukarda izah ettiğimiz iradların yekûnu üzerinden alınır. Bazı zaruri istisnalardan sarfınazar edilirse, mükellefler gelirlerini beyanname ile bildirirler. Gelir vergisi kanununda ve vergi usulüne müteallik Reichsabgabenordnung'da muhtelif kazanç nevilerinin ve gelir fazlalarının nasıl hesap edileceğine dair bir takım hükümler vazedilmiştir :

Gelir vergisi kanununun 4 üncü paragrafına göre, kâr, işletmenin sene başındaki sermayesi ile sene sonundaki sermayesi arasındaki farka müsavidir. Ancak, mükellefin sene içinde şahsî ihtiyaçları için çektiği meblağın kâra ilâvesi, işletme sermayesine yaptığ ${ }_{1}$ ilâveler ise, kârdan tarhedilmesi icabeder.

Ticaret sicilline kayıtlı mükellefler için kârı tesbit etmek büyük bir hususiyet arzetmez. Bu nevi mükellefler, ticarî sene sonunda defterle- 
rindeki kayitlara göre bilânço tanzim edeceklerinden, bu bilânçolardan işletme sermayelerindeki artma ve eksilmeleri kolayca tesbit etmek kabildir. Bununla beraber, gelir vergisi kanununun, bilânçoya giren kıymetlerin taktirinde bir takım hususî hükümler vazettiğini de unutmamak icabeder: $6,7,7 \mathrm{a}, 7 \mathrm{~b}, 7 \mathrm{c}, 7 \mathrm{~d}$, ve $7 \mathrm{e}$ paragrafları gibi.

Bu hükümlere nazaran, sabit sermayeye dahil malların krymeti istihsal maliyetinden veya mübayaa fiyatından aşınma payı indirilmek suretiyle hesap edilir (paragraf: 6). Malların yekûn tesisat içindeki değeri, münferit değerlerinden daha düşük ise, bu değer tercih edilebilir.

Aşınma payı (amortisman), makinelerin işletme geleneklerine göre tayin edilen ömürlerine göre hesap edilir. Fakat kanun, fevkalâde teknik ve iktisadî aşınmanın nazarı itibare alınmasına da cevaz vermiştir. Maden cevherindeki azalmalar sübstansdan düşülebilir.

Kanun, harpten sonra mesken inşasını ve gemi imalini teşvik maksadiyle hususî hükümler koymuştur: \% 80 mesken ihtiyacına cєvap veren inşaatta, ilk sene inşa bedelinin \% 10 nunun, müteakip 10 sene $\% 3$ ünün amortisman olarak ayrılması kabul edilmiştir. Ancak onuncu seneden itibaren, binanin tahmini ömrüne göre normal bir şekilde hesap edilen aşınma payı değerden indirilmektedir.

Bu hüküm Alman Devletinin 1948 para reformundan sonra mesken inşaatını teşvik maksadiyle yaptığı direkt sübvensiyonlar yanında (11), dolayısiyle bir himaye teşkil etmektedir.

7c paragrafında daha ileri gidilerek, vergi mükellefinin kârından muayyen tip mesken inşası için faizsiz olarak verilen kredilerin ve Zuschuss'ların işletme masraf $ı$ olarak matrahtan indirilmesi kabul edilmiştir.

Gemi inşasını tesvik maksadivle buna müșabih hükümler mevcuttur, (paragraf: 7d).

Ticaret kanununa göre defter tutmak mecburiyetinde olmiyan mükellefler, işletme sermaye veya kazançları muayyen haddi aşıyorsa (12), kazançlarını tayine imkân verecek şekilde defter tutmağa mecburdurlar. Aksi taktirde basit bir kazanç hesabiyle iktifa edilir. Yani, işletme varidatı ile masrafları arasındaki fark bulunur.

$\mathrm{Bu}$ usullerle gelirin tesbitine imkân bulunmiyan yerlerde ise, kanun gelirin tahmini olarak tesbitine salahiyet vermistir (13). Bunun için ortalama nisbetler (Durchschnittsaetze) ve direktif nisbetler

(11) W. Glootz: Die Entwicklung des Wohnungsbaus und seine Finanzierung, in: Wirtschaftsdienst, Januar 1953.

(12) Reichsabgabenordnung, Paragraf: 161:

(13) Reichsabgabenordnung, Paragraf: 217. 
(Richtsaetze) den istifade edilir. Ortalama nisbetler, bilhassa ziraatte işe yaramaktadır. Bununla beraber, muntazam defter tutmiyan, defterleri hakikate uymıyan veya muamele yekûnu Maliye Bakanlığı tarafından tesbit edilen haddi aşmıan bütün mükellefler hakkında da tatbik edilmektedir (paragraf: 29).

Direktif nisbetlere gelince, bunlar muamele hacmi ile kazanç miktarı arasındaki mutat nisbetlere istinad etmektedir: İki işçi çalıştıran bir firmcinin mutad kazancl, muamele yekûnunun \% $6-8$ nisbetinde olduğunu kabul etmek gibi (14).

Bu izahatımızla ziraî, ticarî ve serbest meslek erbabı kazançlarının nasıl tesbit edildiğini ana hatları ile hülâsa etmiş bulunuyoruz. Ücretler, menkul sermaye iradları, icar ve rantlar ve sair iradlara gelince, bunlar umumiyetle gayri safi irad şeklinde elde edildiklerinden, bundan iradın elde edilmesi için sarfedilen gerekli masraflar çıkarılmak suretiyle gelir vergisine matrah teșkil eden safi irad elde edilir.

O halde, gelir vergisi kanununun ikinci paragırafının $4-7$ numaraları ile bildirilen irad nevilerinin bir gelir, birde gider tarafı vardır. Bu türlü gelirlerin vergiye tabi tutulması için mutlaka para seklinde elde edilmesine de lüzum yoktur. Yiyecek, sair mallar gibi ayın olarak elde edilen iradlar da nazarı itibare alınmaktadır. Bu türlü malların, istihlâk yerlerindeki mutad vasati fiyatlara göre değerlendirilmesi icabeder.

Giderlere gelince, bunların gelirden düşürülebilmesi için, gelirin elde edilmesi, emniyet altına alınması ve muhafazası için sarfedilmiş olması icabeder: Gelirle doğrudan doğruya ilgili borç faizleri, mükellefin çalıştığı yerin bina vergisi, meslekî birliklere ödenen aidat, mükellefin evinden is yerine gelip gitme masrafı, iş vasıtalarının temini için sarfettiği paralar, meselâ alet, iş elbisesi satın alınması masrafları ve bunlarin yıpranma payları gibi. Bu nevi masrafların gayri safi iraddan endirilmesine cevaz verilmiştir. Buna mukabil, askerî taahhütlerden, amme borcundan, vergi bonosundan mütevellit zararlar nazarı itibare alınmazlar.

$\mathrm{Bu}$ suretle hesap edilen kâr ve iradların yekûnu mükellefin vergiye tabi gelirini teşkil eder. Gelir vergisi kanunu, matrahın tayininde, yukarda saydığımız tenzilata ilâveten, bazı hususî masrafların tenzilini de kabul etmiştir (paragraf: 10). Bunları şu şekilde hülâsa etmek kabildir:

(14) Neumark: Türkiyede ve yabancı memleketlerde gelir vergisi, Istanbul 1946. 
1. Safi kazancin temininde, işletme masrafi olarak hesap edilmemiş bulunan, azami 800 Marka kadar olan borç faizleri (Meselâ mükellefin, çocuklarının tahsili için aldığ

2 - Sigorta aidatları, mesken tasarruf sandıklarına kredi temin etmek maksaiyle ödenen aidat, mesken kooperatiflerinin hisselerinin ilk defa elde edilmesi için yapılan sarfiyat (15),

3 - Tacir, çiftçi ve serbest meslek erbabının son üç sene zarfında tesviye edilmemiş zararları,

4 - Ödenmis kilise vergileri,

5 - Ödenmiş servet vergileri ilh..

Görülüyorki, Alman Gelir Vergisi Kanunu bu maddeyi kabul etmekle, vergi kudretini geniş ölçüde nazarı itibare almak hedefini gütmekte, mesken inşaatını teşvik maksadiyle yeni bir vasıtalı himaye ortaya koymaktadır. Buna mukabil, mükellefin ailesinin ve kendisinin geçimi için sarfettiği paraların matrahtan endirilmesi kabul edilmemiştir (paragraf: 12).

Vergiden muaf olan iradlar (paragraf: 3) :

Gelir mefhumuna nelerin girdiği ve gelirin ne şekilde tesbit edildiğini gördükten sonra, vergi nisbetlerine, tarh ve tahsile geçmeden önce, bir kısım iradların vergiden tamamen muaf tutulduğuna işaret etmemiz icabeder. 29 nisan 1950 tarihli tadilata göre, muafiyete tabi iradlar şunlardır :

1. Hastalık ve kaza sigortasından alınan maaş ve tazminatlar, işçi ve müstahdemlerin kanunen teminat altına alımıs rant gelirleri,

2. İşci ve müstahdemlere ihtiyarlık sigortasından, memurlara emeklilik kanunu gereğince iade edilen aidat (Kapitalabfindung),

3. İşçi ve müstahdemlerin ihtiyarhk sigortasından aldıkları tekaüdiyeler (Fakat bu tekaüdiyelerin vergiye tabi olmaması için senelik tutarının 600 Markı geçmemesi lâzımdır. Bununla beraber, 3600 Marka kadar olan tekaüdiyelerde vergi hesap edilirken, 600 Marklık bir indirim yapilir.)

4. İssizliğin himayesi maksadiyle, kanunen işsizlere ödenen ücretler,

5. Kanuna uygun olarak harpten zarar görenlere ve geride kalan dul ve yetimlere ödenen paralar,

(15) $\mathrm{Bu}$ son iki istisna, harpten sonra Almanyada mesken inşasını teşvik için alunan diger tedbirlerle birlikte mütalâa edilmelidir. 
6. Kanununa göre yapılan bazı acil yardımlar,

7. Nasyonalsosyalist idarenin haksiz muamelesi neticesinde uğranılan zararların kanunen telafisi için ödenen tazminat ve iradlar,

8. İ kanunu gereğince işten çıarılanlara ödenen tazminat ve intikal ücreti,

9. Bazı şartlar dahilinde, resmi kaynaklardan ve vakıflardan alınan burslar, paralar,

10. Memur harcirahları,

11. İsveren tarafından işçilere, 300 - 500 Markı aşmamak üzere tediye edilen evlenme ve doğum ikramiyeleri ilh..

Görülüyorki, gelir vergisinde yaprlan istisnalar, daha ziyade sosyal gayeye istinad etmektedir.

\section{Verginin tarhı :}

Gelir vergisi, üçüncü paragrafda vergiden istisna edildiği bildirilen iradlar dışında, hakikî şahısların bir yıl zarfında temin ettikleri safi kazanç ve iradların yekûnu üzerinden hesap edilir.

Tarh ameliyesi, iradın kazanıldığı malî yılı takip eden yıl içinde yapilır. Bununla beraber, vergi mükellefiyeti daha önce sona erdiği taktirde, tarhin derhal yapılmasi icabeder (paragraf: 25).

Gelir vergisinde mükellef hakikî şahıslar olmakla beraber, kanun ailenin yekûn gelirini esas olarak almıștır. Muayyen bir yaşi geçmeyen ve aile ile birlikte yaşıyan çocukların ve kadım temin ettikleri gelirler, aile reisi olan erkeğin gelirine ilâve edilmek suretiyle meydana gelen aile geliri, verginin matrahını teşkil etmektedir.

Bununla beraber, gelir vergisi kanununun, bazı istisnaî hallerde istihlậk masraflarını matrah olarak kabul ettiğini de unutmamak icabeder. Ezcümle, 48 inci paragrafda, istihlâkin 10000 Markı aşması - bu miktara her çocuk için 2000 Mark ilâve edilmesi lâzımdır. - ve gelirden \% 50 fazla bulunması halinde, malî idarenin masrafları matrah olarak intihap edebileceği derpiş olunmaktadır. İstihlâk masraflarına nelerin dahil edilip edilmiyeceği aynı paragrafın ikinci ve üçüncü fıkralarında bildirimliştir.

Ístihlâk masrafı üzerinden alınan vergi, aynı miktardaki gelir üzerinden alınan verginin yarısina tekabül etmektedir. Bu hale nazaran, vergi idaresi, gelir veya masraf üzerinden tarh edilen vergilerden hangisi daha yüksekse, onu tercih eder. 
Vergi nisbeti (paragraf: 32 ):

1920 tarihli gelir vergisi kanununda vergi tarifesinin \% $10-60$ arasinda tesbit edildiğini tarihçe kısminda zikretmiştik. Aynı kanuna göre, kadın, çocuklar, yaşlı ve malûl kimseler için kanunda derpiş edilen tenzilat vergi üzerinden yapılmak idi (16).

1925 vergi kanunu bu usulü terkederek geçim indirimi sistemini vazetmiştir. Yani indirim vergi tarh edilmeden önce, vergiye mevzu gelir üzerinden yapılmaktadır.

Muhtelif tadillere rağmen; bu esas zamanımıza kadar muhafaza edilmiştir. Zamanımızda carî olan Alman gelir vergisi kanununa göre asgarî geçim indirimi bakımından mükellefler üç sınıfa ayrılmıştır :

1. Bekârlar,

2. Evliler (gelir devresinin en az son dört ayında evli olanlar) ve 65 yaşını geçmiş bulunan bekârlar (aynı şekilde gelir devresinin son dört ayında 65 yaşını doldurmuş olmak icabeder) ve 50 yaşını geçmiş bulunan dullar,

3. Çocuk indiriminden istifade edenler. Cocuk indiriminden 18 yaşını bitirmiyen cocuklarla 25 yaşını bitirmiyen, mükellef tarafindan bakılan tahsildeki çocuklar istifade ederler.

Çocuk mefhumu kanun tarafından geniş mânada kabul edilmiştir: Öz ve övey çocuklar, evlatlıklar, evlilik dışı çocuklar arasında fark gözetilmemiştir. Çocuk indiriminden faydalanan mükellefler çocuk adedine göre gruplandırılmıştır. Binaenaleyh, mükelleflerin üç sınıfa ayrılması zahiridir. Hakikatte müteaddit sinfflar mevcuttur.

Vergi miktarı, muhtelif smıflara ve gelir miktarına göre tablo halinde tesbit edilmiştir. 24 Haziran 1953 tarihli gelir vergisi tadilatına göre, vergiden muaf tutulan en az geçim indirimi, birinci sinıf vergi mükellefleri, yani evli olmıyan şahıslar için 800 Mark, ikinci sınıf mükellefler için 1600 Mark, bir çocuklu evliler için 2200 Mark, iki çocuklu evliler için 2800 Mark, beş çocuklu evliler için 5350 Mark'tır. Bunu takip eden her çocuk için 840 Mark indirilmesi kabul edilmiştir. Bu hale göre, yıllık geliri 5351 - 5400 Mark arasında bulunan bir mükellef birinci sinffa dahil ise, 811 Mark, yani $\% 15$ nisbetinde bir vergi ödemesi lâzım geldiği halde, beş cocuklu bir aile reisi onbinde sekiz gibi bir vergi vermesi icabetmektedir. Fakat gelir yükseldikçe, aradaki bu muazzam fark azalır. Meselâ tarife listesinde en son olarak bildirilen 99.901 100.000 Mark arasında gelir alan birinci sınıf bir mükellefin 48.623 mark,

(16) Neumark: Einkommensteuer... S. 257. 
yani \% 48,9 nisbetinde, buna mukabil ikinci sinı mükelleflerin 48.143 , yani \% 48,4 nisbetinde, beş çocuklu bir aile babasının - ki, listede dokuzuncu gurubu teşkil etmektedir - 45.911 Mark, yani \% 45 nisbetinde vergi ödemesi icabeder.

Birinci sınıf mükelleflerin 100.000 den yukarı gelirleri 130.000 Mark'a kadar \% 65, 130.000 Mark'tan 170.000 Mark'a kadar \% 70, 170.000 Mark'tan 220.000 Mark'a kadar \% 75, 220.000 Mark'tan 423.500 Mark'a kadar olan gelirler \% 80 vergiye tabi tutulmuştur. Bunun üstündeki gelirler için vergi nisbeti \% 70 dir.

Ikinci ve üçüncü sinıf mükelleflerin vergileri biraz evvel zikrettiğimiz asgarî geçim indirimleri yapıldıktan sonra kalan meblâğ üzerinden hesap edilir (17).

$\mathrm{Bu}$ tarifede, fevkalâde masraf ve gelirler için tenzilat yapılmasına cevaz veren haller mevcuttur. Gelir Vergisi Kanununun 33 üncü paragrafına nazaran, vergi ödeme kabiliyetini sarsan, fevkalâde bir masrafla karşılaşan bir mükellef, gelir vergisinde tenzilat yapılmasını istiyebilir. 1925 tarihli Gelir vergisi kanunu, böyle bir tenzilatın yapılabilmesi için 20 - 30 bin arasında asgarî bir gelir şartı koşmuştu. 1941 den sonra bu hüküm kaldırılmıştır. Bununla beraber, tenzilat teklifinin kabul edilip edilmemesi Maliye idaresinin taktirine bırakıldığından, böyle bir kaydın kaldırılmasının mühim bir tesiri olmamıștır (18).

Fevkalâde masraflarda olduğu gibi, fevkalâde iradlar için de mükellef tarafindan tenzilât talen edilebilir. Gelir Vergisi Kanununun 34 üncü paragrafına göre, sınaî, ziraî işletmelerin satılmasından elde edilen kazançlar, bir kaç yıl devam eden bir faaliyetin mukabilinde elde edilen iradlar fevkalâde irad olarak kabul edilmektedir.

Bu türlü gelirlere, mükellefin talebi üzerine, umumî tarife yerine, \% 10 - 40 arasında bir tarife tatbik edilir. Fakat bunun için fevkalâde gelirin 6000 Mark'ın üzerinde olması icabeder. Vazı kanun, bu suretle müterakki umumî tarifenin gayrı muntazam gelirlere tatbikinden doğacak adaletsizliği önlemek istemiştir. Bilhassa serbest meslek erbabı için bu maddenin büyük bir ehemmiyeti vardır. Meselâ bir avukatın bir kạ̧ yıl devam eden bir dâvasından temin ettiği gelirin yekûnunun umumî tarifeye tabi tutulması adaletsizlik yaratır.

$\% 10$ - 40 arasında hangi nisbetin tatbik edileceği malî idareye blrakılmıştır.

(17) Bundessteuerblatt, herausgegeben vom Bundesminister der Finanzen, Teil 1, Nr. 15/16, Bonn 29 Juni 1953.

(18) Neumark : Einkommensteuer... S. 262.

Einkommensteuergesetz vom 1949 , paragraf : 33 . 
Menbada kesilen ücretlerin gelir vergisi için ayrı bir tarife tablosu tanzim edilmiştir. Umumî tarifede olduğu gibi, ücretlerden kesilen vergilerin hesabında da bazı hususî münasebetler nazarı itibare alınmaktadır. İşçi, işi ile ilgili masraflarından senede 312 Mark'ı (ayda 26 Mark) aşan kisminin matrahdan tenzilini istiyebilmektedir (paragraf: 41).

Ayrıca, üçüncü paragraf anlamında hususî masrafların tamamı veya senede 312 Mark'ı aşan kısmı,

İşçi ve mütahdemin vergi ödeme kabiliyetini sarsan fevkalâde masraflarmdan Maliye idaresinin takțir edeceği bir miktar vergi matrahından tarholunabilir.

Maliye idaresi, tarholunan meblağı ücret vergi karnesi üzerine kaydeder. Tenzilat ücretin tediyesi anında yapılır. 42 inci paragrafa göre, işçi işe başlamadan evvel, belediyede bir ücret karnesi tanzim ettirerek, bunu iş verene arzetmeğe mecburdur. İş veren ücret vergi karnesini is müddetince muhafaza eder.

\section{Verginin tahsili :}

Alman gelir vergisi yekûn kazaņ̧ ve gelir fazlası üzerinden alınmakla beraber, bir kısım vergilerin menbada kesilmesi esası kabul edilmiştir. Bu bakımdan Alman Gelir Vergisi'nin sentetik ve analitik vergi sistemleri arasında yer aldığı söylenebilir. Meselâ ücret ve maaşlardan alınan vergi, ücret ve maaşın tediyesi anında kesilir. Işveren, işçi, müstahdem ve memurlarma ödediği ücret ve maaşların vergilerini tediye esnasinda keserek, maliye idaresine yatırmakla mükelleftir (paragraf: 38 ). Vergi mükellefi iş̧̧i olmakla beraber, işveren verginin kesilerek maliyeye yatırilmasindan mesuldür.

Menbada kesilen vergilerden ikincisi, menkul sermaye iradı üzerinden alman vergidir. Dividant, faiz gibi menkul sermaye iradlar, sahiplerine ödenirken \% 25 vergi tevkifatı yapılır. Borçlu yaptığı vergi tevkifatım bir hafta içinde maliye idaresine yatırmakla mükelleftir (paragraf: 44).

Menbada kesilen bu vergilere muvazi olarak, kanun, beyannameye göre tarhı yapılan yekûn gelirin vergisi için de alelhesap tediye mecburiyeti koymuştur. Yani mükellef, gelirin kazanıldığı sene içinde, ilerde hakikî gelirine göre tahakkuk ettirilecek olan gelir vergisi ile mahsubu yapılmak üzere peşin tediye ile mükellef tutulmuştur. Paragraf: 35 de, peşin tediyenin 20 Nisan, 20 Temmuz, 20 Ekim ve 20 Ocak olmak üzere dört taksitte yapılması emredilmiştir. Taksitler, bir evvelki üç aylık gelire göre hesaplanır.

Peşin olarak ödenen taksitler ve menbada kesilen vergiler, malî sene hitaminda beyannamelere istinaden hesap edilen vergi tutarından 
azsa, fark mükelleften tahsil olunur. Fazla ise, fazla mükellefe iade ediIir (paragraf: 47). Bununla beraber, kanun, ücret ve maaşlardan kesilen vergilerin mahsubu için bazı şartlar koşmuştur. (Paragraf: 46). Bu şartlar mevcut olmadiğı taktirde, kesilerek tahsil edilen vergi nihaidir.

\section{KURUMLAR VERGISI}

Almanyada 1891 tarihinden beri gelir vergisinin yanında, bir kısım şirketlerin gelirlerini istihdaf eden kurumlar vergisinin tekâmül ettiğini görüyoruz. Bu suretle doğrudan doğruya olmasa bile, bir mükerrerlik yaratılmak, sirket kazançları üzerinden daha yüksek vergi almak gayesi güdülmüştür. Filhakika, kurumlar vergisinin gerekçesinde, kurumların hakikî şahıslara nazaran daha büyük bir ödeme kudretine sahip olduğu zikredilmektedir. Kurumlar vergisi ,vergide ayırma prensibinin tahakkukuna yardım etmektedir.

Kurumlar vergisine giren mükellefler, esas itibariyle sermaye şirketleridir: Anonim şirketlex, sermayesi eshama münkasim komandit şirketler, limitet şirketler gibi. Bunun yanında deniz aşırı ticaretle iştigal eden şirketler, maden hukukuna tabi sendikalar, kooperatifler, mütekabiliyet esasına dayanan sigorta sirketleri, amme hukukuna tabi ticarî islletmeler, hususî hukuka tabi diğer bazı müessese ve tesisler, nihayet gelir vergisine tabi bulunmadıkları taktirde, hukukî şahsiyeti bulunmiyan şirketler aynı șekilde kurumlar vergisine tabidir.

Kurumlar vergisine tabi mükellefler, hakikî şahısların gelir vergisinde olduğu gibi, 1 . İdare merkezleri veya ikametgâhları Almanyada bulunduğu taktirde bütün gelirleri üzerinden vergiye tabi tutulmuştur. (Tam mükellefiyet). 2. İdare merkezleri veya ikametgâhları Almanyada bulunmadığı taktirde, sadece Almanyada kazandıkları gelir üzerinden vergiye tabi tutulmuslardır (dar mükellefiyet), (paragraf: 1 ve 2). 1950 tarihinde gelir vergisinde yapilan tadilata uygun olarak, kurumlar vergisi ikinci paragrafma bir fikra eklenmek suretiyle, idare yeri veya ikametgâhı Federal Almanyaya ait sayilan kurumlar da dar mükellefiyete tabi tutulmuşlardır.

\section{Vergiden muaf tutulan kurumlar :}

1. Alman P.T.T. idaresi, Devlet Demiryolları, Tekel idareleri, Devlet Piyango idaresi;

2. Reichsbank, Alman Memleketleri Bankasi, Deutsche Rentenbank, Deutsche Rentenbak - Kreditanstalt;

3. Bir kısım devlet bankaları;

4. Amme tasarruf sandıkları ve ammenin kontrolüne tabi tasarruf sandikları; 

tifler;

5. Muayyen şartlar dahilinde Orman ve Keresteciliğe ait koopera-

6. Din, içtimaî muavenet gayesi ile kurulan ve ammeye hadim tesisler;

7. Hükmi şahsiyeti haiz, ihtiyarlık, hastalık, dul ve yetim sandıklari;

8. Kâr gayesi gütmiyen meslekî teşekküller (İşçi sendikaları, işveren birlikleri (19);

9. Şahsiyet sahibi olmıyan meslekî birliklerin mallarını idare gayesiyle kurulan anonim ve limitet sirketler

kurumlar vergisinden muaf tutulmuşlardır. Dar mükellefiyete tabi olan kurumlar bu muafiyetlerden istifade edemezler (paragraf: 4).

Kurumlar vergisine tabi olan gelirin tayinine gelince (paragraf: 5). hakikî şahısların gelir vergisinde olduğu gibi, kurumların bir takvim yılı içinde temin ettikleri yekûn iradları tesbit edilir. Esasen kurumlar vergisi kanununun altmeı paragrafı, kurumlarin iradlarmın tayininde, gelir vergisinin 7 - 16 incı paragraflarına atıf yapmaktadır. Ancak, kurumların gelirleri tesbit edilirken, gelirin tevzi edilip edilmemesinin bir ehemmiyeti yoktur. Ne sekilde olursa olsun, tevzi edilen temettular, hattâ gizli kâr dağıtımı gibi şirket gelirini azaltan ameliyelere cevaz verilmemiştir. Bu suretle meselâ idarecilere normal ücretlerin fevkinde fevkalâde üksek ücret vermek suretiyle vergi kaçakcılığına mâni olunmak istenmiştir.

Buna mukabil, tam mükellefiyete tabi bir şirketin, yine tam mükellefiyete tabi diğer bir sirketin $1 / 4$ hisse senedine malik olması halinde (Verschachtelungsgesellschaften), üç taraflı bir mükerrerliğe mâni olmak maksadiyle, kanun bu hisselere düşen kazançları kurumlar vergisinin dişında tutmuştur. Bilhassa, konzern'lerde durum böyledir.

Bundan başka bazı hususî masrafların şirketin gelirlerinden indirilmesine cevaz verilmiştir. Ezcümle, 11 inci paragrafta bildirildiği gibi, bir şirketin esham ihracı masrafları, komandit şirketlerin gayrı mahdut surette mesul ortaklara ödedikleri Tantiem'ler, şirketin malî durumunu islah maksadiyle borçların tecili suretiyle temin edilen kazançlar, bazı dinî, sosyal ve hayır maksadiyle yapılan masrafların matrahtan indirilmesi kabul edilmiştir.

Buna mukabil, gelir ve servet vergileri, idare meclisi üyelerine ve mürakiplere ödenen huzur hakları ilh. matrahtan indirilemezler (pa-

(19) Verordnung zur Durchführung der Körerschaftsteuer, Paragraf : 13. 
ragraf: 12). Keza, şirketin tasfiyesinden veya başka şirketlerle birleşmesinden temin edilen kazançlar kurumlar vergisine tabidir (paragraf: 7).

\section{Vergi Tarifesi :}

Haziran 1953 de yapılan tadilata göre, sermaye şirketleri, istihsal kooperatifleri, mütekabiliyete dayanan sigorta şirketleri, devlet ticarî teşekkülleri ve yabancı hukuklara göre teşekkül etmiş mümasil teşebbüsler, sirket geliri üzerinden \% 60 kurumlar vergisine tabidirler. Diğer kurumlarm vergisi \% 50 dir.

Fakat bazı kurumlara tenzilatlı tarife tatbik edilmektedir: Ezcümle, 1) Amme hukukuna tabi kredi müesseselerinin, belediye hizmetleri ve ameliyorasyon maksadiyle verdikleri kredilerden ve reel ikrazlarından temin ettikleri iradları,

2) Ípotek bankalarmın gelirleri,

3) Mixt ipotek bankalarının, ipotek bankaları kanununa göre yaptıkları muamelelerden temin edilen kazançları,

4) Hususî mesken tasarruf sandıklarının uzun vadeli kredi muamelelerinden elde ettikleri kazançlar ve dur (20).

5) Gemi irad senedi bankalarının iradları için vergi nisbeti $\% 30$

Kurumlar vergisinin tarh muamelelerine, gelir vergisinin tarhı için carî olan hükümlerin tatbik edileceği kabul edilmiştir (paragraf: 20). Paragraf: 21 de, kurumun vergiye tabi gelirinin cüz'i ve tesbitinin fazla masraflı bulunduğu hallerde malî idareye, kurumlar vergisini götürü olarak tesbite salahiyet vermektedir.

Bundan başka, hakikî şahısların gelir vergisinde, verginin bazı hallerde masrafdan alındığı gibi, kurumlar vergisi kanunu, şirketin dağıttığı temettuun, tediye edilmiş şirket sermayesinin \% 4 ünü aşan kısmı, idare meclisi ve mürakiplere verilen ücretler, müdürlere mutadın üstünde ödenen meblağlar, şirketin beyannamesinde gösterdiği kazancından fazla ise, vergi bu masraflar üzerinden alınabilir (21).

\section{Vergi prensipleri ve Alman Gelir Vergisi :}

Alman gelir vergisinin, hakikî şahısların gelirleri üzerinden alınan gelir vergisi ve sirketlerin gelirlerini istihdaf eden kurumlar vergisi namı altında birbirinden ayrı iki vergiden terekküp ettiğini gördük.

(20) Hans Görbing : Körperschaftsteuer, der Steuertarif, in : Neues Steuerrecht, Lieferung 174 vom 1/11/1953.

(21) Hans Görbing : Körperschaftsteuer, der Steuertarif, in : Neues Steuerrecht, Lieferung 176 vom 1/12/1953. 
Schmölders gibi bazı müellifler, şirketlerin gelir elde etmek için bir vasıtadan başka bir şey olmadıklarmn, kelimenin hakikî mânasında ancak hakikî şahısların gelirlerinden bahsedilebileceğini iddia ederek, hakikî şahısların yanında bir kısım şirketlerin gelir vergisine tabi tutulmasına itiraz etmişlerdir.

Kurumlar vergisi, bir kısım sirketlerin hissedarlarının çifte vergi ödemelerine sebebiyet vermekte, bazı kurumların vergiye tabi tutulması, diğer bazılarının kurumlar vergisine dahil edilmemesi vergide müsavatsızhğa sebep olmaktadır (22).

Kurumlar vergisine karşı yönetilen bu itirazların hakikat hissesinin mevcut olduğu söylenebilir. Ancak, kurumların ayrı bir vergiye tabi tutulması ayırma prensibine uygun telâkki edilmektedir. Bununla beraber, vergi önünde muhtelif kurumlar arasında fark gözetilmesi ve küçuk, büyük bütün kurumların seyyanen \% 50 - 60 nisbetinde vergiye tabi tutulması, vergi kudretinin nazarı itibare alınmadığının bir delilidir. Bununla beraber, şirketlerin gelirlerini hakikî şahısların gelirleri ile bir tutmak doğru değildir. Şirketler gelirlerin son süjesi değildir. Şirketlerin elde ettikleri kazançlar ortaklara intikal etmektedir.

Kurumlar vergisini, iktisadî tesirleri bakımından, muamele vergisi gibi mütalâa eden maliyeciler bile mevcuttur. Bu maliyecilere göre, kurumlar vergisi ile adeta eski objektif vergilere dönülmüştür (23).

Kurumlar vergisi, muayyen derecede mükerrerliğe sebep olmaktadır. Netekim, 1920 kanununda bu mükerrerliğe mâni olmak maksadiyle, matrahdan, kurum sermayesinin \% $2-3,5 \mathrm{u}$ nisbetinde bir indirim yapılması kabul edilmişti. 1925 kanununundan sonra bu tenzilat kaldırılmıştır. Bu hal, bilhassa menkul sermaye iradları bakımından müsavatsızlığı mucip olmaktadır. Zira, menkul kıymet sahipleri, kurumlar vergisi kesildikten sonra, ayrıca sermaye irad vergisi ödemektedirler ki, Schmölders'in iddiasına göre, menkûl kıymet sahipleri, ziraî işçilerden daha fena duruma sokulmus olmaktadır. Bu ise, Almanyanın bu gün çok muhtaç bulunduğu sermaye teşekkülüne büyük bir engeldir.

Bunun gibi, son 40 sene içinde hakikî şahısların gelir vergisi nisbetlerinde husule gelen değişiklikler sermaye terakkümünü güçleştirmektedir. Schmölders'e göre, son 40 sene içinde vergi nisbetlerinde görülen yükselmeler bilhassa yüksek gelirlerde kendisini göstermiştir. Meselâ 10.000 Marklık bir gelirin gelir vergisi dört misli artırıldığı halde, 100.000 Marklık gelirin vergisi altı misli yükseltilmiştir.

(22) Schmölders: Die Notwendigkeit der organischem Steuerreform...

(23) Schmölders: Das Deutsche Steuersystem. 
Buna mukabil, aşağı gelirlerde bir ferahlama mevcut değildir. Bilâkis muafiyet hududu bir hayli daralmıștır. Filhakika, para değerinin durmadan düşmesi, daha az gelirli kimseleri mükellefiyete tabi kılmısstix. Paranın değerindeki düşmeler neticesinde nominal ücretlerde husule gelen yükselmeler, kısmen vergi tarafından massedilmiştir. Bu neticeye bakarak gelir vergisinin vasitalı vergilerden daha gayri âdil olduğunu iddia edenler bile vardır. Fakat devlet masraflarından en fazla bu smufların istifade ettiğini de unutmamak icabeder.

Bir kisım Alman maliyecileri, gelir vergisinde umumiyet prensibinin tam olarak gerçekleştirilmediğini iddia etmektedirler. Eskiden bazı sosyal mülahabzalarla tanman muafiyetlerin, bu gün daha fazla genişletildiği söylenebilir. Ezcümle mültęciler ve ziraatte çalışan kimselerin büyük bir kısmı gelir vergisinden muaf tutulmaktadır. Meselâ 1950 de ziraatin Alman millî gelirine iştirâki \% 10 olduğu halde, vergiye iştirâki \% 1 dir. Devlet bütçesinden ziraate ödenen sübvansiyonlar nazarı itibare alınırsa, ziraatin devlete bir şey vermediği, bilâkis devletten yardim aldığı söylenebilir. Umumiyetle Garbi Avrupa Memleketlerinde ne pahasına olursa olsun, muayyen bir ziraî sınıfın muhafazasına gayret edilmektedir.

Bütün bunlar ve bunlara benzer tenkitler, bir vergiden beklenen muhtelif gayelerin birden tahakkuk ettirilmesinin ne kadar güç olduğunu, hattâ mümkün olamıyacağını göstermektedir. 